\title{
EKSISTENSI HUKUM ADAT DALAM SISTEM HUKUM DI INDONESIA
}

\author{
Eka Susylawati \\ (D osen T etap Jurusan Syari'ah STA IN Pamekasan dan peserta Program D oktor \\ IImu H ukum U ntag Surabaya)
}

\begin{abstract}
A bstrak
A traditional law (hukum adat) is a law reflecting an Indonesian character; as a result it has been claimed as the law which is genuinely Indonesian. As an unwritten law, nowadays the existence of traditional law is questionable. It has been judged as conservative, stiff, primitive old fashioned comparing to the development of modern society. Some people argue that traditional law is unable to resolve the problems in this globalization era. In facts, traditional law has become a basic principle to legalize the contemporary laws. For instances, traditional laws inspires the law of UU. No 5 Th. 1960 about the major law of agrarian affairs and the la of UU. No. 1 Th. 1974 about marriage. The relevance of traditional law to current one is supported by the existence of UU. No. 4 Th. 2004 about the authority of judicial affairs, it opens the chance for the judges to execute and decide a case based on traditional laws.
\end{abstract}

Kata Kunci:

hukum adat, adat, hukum agraria, dan harta perkawinan.

\section{Pendahuluan}

Sejak lahir di dunia, manusia telah bergaul dengan manusiamanusia lain di dalam wadah yang disebut masyarakat.1 Semula hubungannya hanya terbatas dengan orang tua, dan semakin hari pergaulannya akan semakin luas. Dengan semakin luasnya hubungan antar manusia tersebut, kemudian dibuatlah pedoman yang merupakan aturan bagi masyarakat tersebut.

1 Soerjono Soekanto, Pokok-Pokok Sosiologi Hukum, (Jakarta: RajaGrafindo Persada, 1999), hlm. 1 
Kaidah-kaidah dan nilai-nilai yang menjadi pedoman dalam mengatur kehidupan masyarakat adalah beraneka ragam. Norma hukum merupakan norma yang penting disamping norma agama, kesopanan dan kesusilaan. Norma hukumpun di dalam masyarakat beraneka ragam, yang meliputi hukum tertulis dan hukum tidak tertulis.

Setiap masyarakat di seluruh dunia mempunyai tata hukum di dalam wilayah negaranya. Tidak ada suatu bangsa yang tidak mempunyai tata hukum nasionalnya. Hukum nasional bangsa merupakan cerminan dari kebudayaan bangsa yang bersangkutan. Karena hukum merupakan akal budi bangsa dan tumbuh dari kesadaran hukum bangsa, maka hukum akan tampak dari cerminan kebudayaan bangsa tersebut.2

Di Indonesia, salah satu hukum yang merupakan pencerminan kepribadian bangsa adalah hukum adat, yang merupakan penjelmaan jiwa bangsa tersebut dari abad ke abad. ${ }^{3}$ Adat yang dimiliki oleh daerah-daerah adalah berbeda-beda, meskipun dasar serta sifatnya satu yaitu ke-Indonesiaannya.4 Oleh karena itu adat bangsa Indonesia dikatakan merupakan Bhinneka Tunggal Ika, yang artinya berbedabeda, tetapi tetap satu. Adat tersebut selalu berkembang dan senantiasa mengikuti perkembangan masyarakat dan erat hubungannya dengan tradisi rakyat. Dengan demikian adat merupakan endapan (renapan) kesusilaan dalam masyarakat, yang kebenarannya telah mendapat pengakuan umum dalam masyarakat tersebut.

Adat istiadat pada hakikatnya sudah ada pada zaman kuno, yakni pra masuknya agama Hindu ke Indonesia. Pada waktu itu adat yang berlaku adalah adat-adat M elayu-Polinesia. Lambat laun kultur Islam dan Kristen juga mempengaruhi kultur asli. Pengaruh kulturkultur pendatang tersebut di atas adalah sangat besar sehingga akhirnya kultur asli yang sejak lama menguasai tata kehidupan masyarakat Indonesia itu tergeser, dan adat yang berlaku adalah merupakan akulturasi antara adat asli dengan adat yang dibawa oleh

2 Anto Sumarman, Hukum A dat Perspektif Sekarang dan M endatang, (Yogyakarta: Adi Cita Karya Nusa, 2003), hlm. 1.

3 Surojo Wignjodipuro, Pengantar dan Azas-Azas Hukum Adat, (Jakarta: Gunung Agung, 1982), hlm. 1

4 lbid. 
agama Hindu, Islam dan Kristen. Dengan demikian dalam perkembangan hukum adat pun di masyarakat sangatlah dipengaruhi oleh ketiga agama tersebut di atas. ${ }^{5}$

Hukum adat merupakan hukum yang tumbuh dari kesadaran masyarakat, yang merupakan pencerminan dari cita rasa dan akal budi budaya bangsa. Dalam perkembangan dan pembangunan di bidang hukum, sering timbul pernyataan, apakah dalam pembentukannya akan menggunakan bahan-bahan hukum adat, yang merupakan hukum sendiri, atau malahan menggunakan hukum dari luar (asing).

Ada sebagian para sarjana yang meragukan tentang kemampuan hukum adat untuk dijadikan dasar atau landasan hukum nasional. Pendapat ini didasarkan pada pendapat dan argumentasi bahwa hukum adat adalah hukum kuno, dan sering disebut hukum primitif, yang hanya cocok untuk digunakan pada masyarakat yang terbelakang. Pendapat ini menimbulkan konsekwensi bahwa hukum adat tidak sesuai lagi bilamana digunakan sebagai hukum bagi masyarakat peradaban modern. Apalagi jika diberlakukan pada era globalisasi saat ini, dimana hubungan masyarakat antar negara tidak lagi ada pembatasan. ${ }^{6}$

\footnotetext{
5 Faktor-faktor yang mempengaruhi hukum adat antara lain: magi dan aninisme, kekuasaan-kekuasaan yang lebih tinggi dari persekutuan, hubungan dengan orangorang dan kekuasaan asing, dan yang paling besar pengaruhnya adalah agama, terutama agama Islam. Pengaruh terbesar adalah dalam hukum perkawinan, sehingga hukum perkawinan Islam sudah menjadi hukum perkawinannya sendiri (telah terjadi resepsi hukum). Bahkan di Jawa dan Madura resepsinya sudah bulat, sehingga perkawinan baru dianggap sah, apabila akad nikahnya dilakukan sesuai dengan ketentuan hukum perkawinan Islam.

6 Seperti halnya dengan hukum yang lain, hukum adat pada awalnya juga mengenal pembidangan, yakni antara lain: hukum negara adat, hukum pidana adat (delik adat), hukum antar bangsa adat dan hukum perdata adat. Hukum negara adat dan hukum antar bangsa adat sudah tidak berlaku yaitu sejak bangsa Indonesia mengalami penjajahan dan terlebih lagi, sejak negara Indonesia merdeka, dengan konsep satu bangsa dan satu negara. Sedangkan dalam bidang pidana adat, sebagian besar tergusur dengan berlakunya Kitab Undang Undang Hukum Pidana (KUHP) dengan asas legalitasnya, yang menyatakan bahwa tidak ada pidana, jika tidak ada peraturan tertulis yang mengaturnya terlebih dahulu. Sedangkan hukum perdata materiil adat yang eksis hingga saat ini antara lain dalam bidang waris, perkawinan, dan kekerabatan.
} 
Di kalangan perguruan tinggi, baik di fakultas hukum maupun di jurusan syari'ah, sampai saat ini hukum adat masih menjadi salah satu dari mata kuliah yang harus ditempuh. Lebih dari itu, penulis juga sering mendengar, baik dari kalangan dosen maupun mahasiswa, yang menyatakan bahwa hukum adat tidak dapat dikategorikan sebagai hukum, melainkan hanya sebagai "kebiasaan" saja. Realitas tersebut juga didukung dengan fakta bahwa hukum adat dewasa ini juga banyak tidak diminati. Hukum adat hanya dianggap sebagai hukum yang usang yang sepertinya tidak layak lagi dipelajari. Sedikit sekali masyarakat maupun kalangan perguruan tinggi yang berminat untuk menekuni hukum adat, hal ini nampak bahwa hasil penelitian tentang hukum adat di Indonesia sangat minim. Dan buku-buku literatur hukum adat pun adalah buku-buku lama, yang hanya diperbaharui tahun penerbitannya saja.

Keadaan ini mengisyaratkan bahwa perkembangan hukum adat akan semakin suram dan kemungkinan tidak akan diminati lagi di kalangan masyarakat akademik pada waktu mendatang. Untuk itu perlu diketengahkan kembali agar hukum adat mendapatkan pemahaman secara lebih baik.

\section{Konsep H ukum A dat menurut Para Sarjana}

Hukum adat adalah istilah yang diberikan oleh kalangan ilmu pengetahuan hukum pada masa silam kepada kelompok, pedomanpedoman dan kenyataan yang mengatur dan menertibkan kehidupan rakyat Indonesia. Kalangan ilmuwan pada waktu itu melihat bahwa rakyat Indonesia, yang hidup di pelosok-pelosok hidup dalam ketertiban dan mereka hidup tertib dengan berpedoman pada peraturan-peraturan yang mereka buat sendiri. ${ }^{7}$

Istilah hukum adat merupakan terjemahan dari bahasa Belanda yaitu A dat Recht. Istilah ini terdapat dalam buku De A tjehers (Orangorang Aceh), yang disusun oleh Snouck Hurgronje pada tahun 1893. Istilah tersebut kemudian dipakai oleh Van Vollenhoven, yang pada waktu itu memang sangat intens meneliti tentang hukum adat,8 dan

\footnotetext{
7 M. Koesnoe, Catatan-Catatan Terhadap H ukum A dat D ewasa Ini (Surabaya: Airlangga University Press, 1979), hlm 122.

8 Van Vollenhoven adalah orang Belanda yang ditugaskan di Hindia Belanda, yang memiliki ketertarikan pada hukum yang berlaku di Indonesia. Buku yang pernah ditulis tentang hukum adat, salah satunya adalah Het Adat-Recht van N ederlandsch
} 
hingga saat ini istilah hukum adat selalu digunakan sebagai istilah teknis yuridis. 9 Saat ini hukum adat masih dalam pertumbuhan, maka tidak dapat dipungkiri adanya berbagai pendapat yang berbeda dalam memahami dan memberikan pengertian tentang hukum adat, baik dari pandangan sarjana Barat dan sarjana Indonesia.

Menurut Van Vollenhoven, hukum adat adalah hukum yang tidak bersumber kepada peraturan-peraturan yang dibuat oleh pemerintah Hindia Belanda dahulu atau alat-alat kekuasaan lainnya yang menjadi sendirinya dan diadakan sendiri oleh kekuasaan Belanda, dan berlaku bagi orang-orang pribumi dan orang-orang Timur Asing.10 Selanjutnya beliau berpendapat bahwa untuk membedakan antara adat dan hukum adat adalah dilihat dari unsur sanksi, sehingga tidak semua adat merupakan hukum adat. Hanya adat yang bersanksi, yang dapat digolongkan sebagai hukum adat.

Pendapat Van Vollenhoven tersebut memperoleh tanggapan dari sarjana hukum adat yang lain, terutama karena sanksi sebagai kriteria pembeda antara adat dan hukum adat. Sanksi dalam sistem hukum barat merupakan ciri utama dari hukum, sehingga jika sanksi dijadikan sebagai satu-satunya ciri untuk membedakan antara istilah adat dan hukum adat, maka hal tersebut sangatlah tepat. Permasalahannya, sudah tepatkah kriteria sanksi tersebut dijadikan dasar untuk memahami hukum adat yang sesungguhnya.11

Menurut M Kosnoe, antara konsep hukum Barat dan hukum adat mempunyai perbedaan. Dalam hukum Barat, individu dipandang sebagai mahluk yang merdeka dan bebas serta mempunyai kepentingan,dan tiap individu tersebut akan berupa keras keinginannya dapat dipenuhi secara maksimal. Untuk itu perlu adanya sanksi sebagai syarat jaminan agar tidak terjadi pelanggaran terhadap hak orang lain. Hal ini berbeda dengan konsep hukum adat,

Indie (Hukum A dat Hindia Belanda). Dia juga yang memetakan bahwa hukum adat di Indonesia dapat dikelompokan dalam 19 lingkaran hukum. Karena hal-hal tersebut di atas Van Vollenhoven sering disebut sebagai Bapak Hukum Adat Indonesia.

9 Bushar Muhammad, Azas-Azas Hukum Adat: Suatu Pengantar (Jakarta: Pradya Paramita, 1994), hlm. 1.

10 Surojo Wignjodipuro, Pengantar dan A zas-A zas H ukum A dat,, hlm.15.

11 Hilman Hadikusuma, Pengantar IImu H ukum A dat (Bandung: Mandar Maju, 1992), hlm. 13 
yang memandang individu sebagai bagian dari masyarakat dan mempunyai sifat kebersamaan dan komunal yang kuat.12

Dalam hukum adat, sanksi (dalam hukum adat sering disebut sebagai hukuman) bukanlah hal yang sangat urgen, karena dalam hukum adat, hukuman adalah upaya memulihkan kembali keseimbangan yang terganggu karena adanya pelanggaran yang dilakukan oleh seseorang di masyarakat. Dan jika pembetulan hukum yang dilanggar sudah dipulihkan kembali kepada keseimbangan yang semula, maka berarti sudah tidak ada permasalahan lagi. Tindakan koreksi terhadap pelanggar hukum tidak selalu diberikan oleh petugas hukum, karena koreksi tersebut juga dapat dilakukan sendiri, misalnya melarikan gadis di suku Dayak. Perbuatan itu mencemarkan kesucian masyarakat yang bersangkutan serta melanggar kehormatan keluarga. Maka untuk memulihkan keseimbangan hukum diperlukan dua macam upaya, yaitu pembayaran denda kepada keluarga dan penyerahan seekor binatang korban kepada kepala persekutuan untuk dijadikan jamuan adat agar masyarakat menjadi bersih dan suci kembali.

Yang kedua adalah pandangan dari Ter Haar, yang menyatakan bahwa hukum adat adalah seluruh peraturan yang diterapkan dalam keputusan-keputusan yang penuh wibawa dan dalam kelahirannya dinyatakan mengikat. Pendapat ini terkenal dengan teori keputusan (beslissingenleer). Dengan demikian hukum adat lahir dari dan dipelihara oleh keputusan-keputusan para warga masyarakat hukum. Lebih dari itu, keputusan-keputusan fungsionaris hukum, bukan hanya yang dihasilkan oleh hakim, tetapi juga termasuk keputusan kepala adat, rapat desa, wali tanah dan petugaspetugas desa lainnya. Keputusan tersebut juga tidak hanya yang merupakan keputusan mengenai sengketa resmi, tetapi juga meliputi keputusan yang berdasarkan nilai-nilai hidup yang berlaku dalam alam kemasyarakatan anggota-anggota persekutuan.13

12 Sifat kebersamaan dan komunal, nampak dalam nilai-nilai universal dari hukum adat, yakni antara lain asas gotong royong, fungsi sosial manusia dan milik dalam masyarakat, asas prsetujuan sebagai dasar kekuasaan umum dan asas perwakilan dan permusyawaratan dalam sistem pemerintahan. Lihat $M$. Koesnoe, CatatanCatatan, hlm. 6. dan Supomo, Bab-Bab tentang H ukum A dat, hlm 20.

13 Surojo Wignjodipuro, Pengantar, hlm.19. 
Hal penting dari apa yang dikemukakan oleh Ter Haar, yang berkait dengan hukum adat adalah adanya keputusan. Latar belakang Ter Haar menyatakan pendapat tersebut karena "hukum" adalah sesuatu yang diputuskan oleh pejabat-pejabat masyarakat yang bertugas menetapkan dalam bentuk keputusan. Dengan teori tersebut Ter Haar mempositifkan hukum adat dan berusaha menemukan jawaban secara teoritis tentang kapan timbulnya hukum adat tersebut. Pendapat Ter Haar tersebut dipengaruhi oleh pendapat John Chipman Gray, yang terkenal dengan teorinya "all the law is judge made law" (semua hukum adalah hukum keputusan) sebagaimana yang dianut oleh negara-negara Anglo Saxon. Logemann tidak sependapat dengan Ter Haar, karena hukum tidak bergantung kepada keputusan. Logemann juga tidak sependapat jika adat akan menjadi hukum adat apabila telah diputuskan oleh hakim. ${ }^{14}$

Pengutamaan keputusan sebagai kadar untuk mengetahui hukum adat sebagaimana dinyatakan oleh Ter Haar, membawa konsekwensi dalam usaha untuk mengetahui hukum adat. Dengan demikian dalam teori ini, untuk menemukan hukum adat perlu dikumpulkan keputusan-keputusan petugas hukum yang sudah tetap. Hal ini berguna untuk dapat memperoleh kesimpulan umum yang terdapat di dalam keputusan yang bersangkutan agar dapat mengetahui persoalan hukum yang tersirat di dalam keputusankeputusan yang bersangkutan.

Pandangan sarjana Indonesia dalam memberikan pengertian tentang hukum adat mengalami suatu perkembangan dengan kesadaran mempunyai hukum sendiri mendorong para sarjana untuk melakukan penelitian untuk menentukan pengertian hukum adat yang baru. Salah satunya yang diajukan oleh Supomo, hukum adat diartikan sebagai hukum yang tidak tertulis di dalam peraturanperaturan legislatif (unstatutory law) meliputi peraturan-peraturan hidup yang meskipun tidak ditetapkan oleh yang berwajib, tetapi ditaati dan didukung oleh rakyat berdasarkan atas keyakinan bahwa peraturan-peraturan tersebut mempunyai kekuatan hukum.15 Pengertian tersebut diperkuat oleh pendapat Sukanto, yang menyatakan bahwa hukum adat adalah kompleks adat-adat yang

\footnotetext{
14 Hadikusuma, Pengantar IImu H ukum A dat, hlm. 15

15 Wignjodipuro, Pengantar, hlm.14.
} 
kebanyakan tidak dikitabkan, tidak dikodifikasi, bersifat paksaan, mempunyai saksi dan mempunyai akibat hukum.16 Dari dua pendapat di atas dapat disimpulkan bahwa hukum adat adalah hukum yang tidak tertulis dalam hidup bermasyarakat maupun dalam lapangan ketatanegaraan.

Pendapat lain dikemukakan oleh Hazairin, yang menyatakan bahwa terdapat persesuaian antara hukum dan kesusilaan.17 Dalam sistem hukum yang sempurna tidak ada tempat bagi sesuatu yang tidak selaras atau bertentangan dengan kesusilaan. Istilah hukum adat tidak dibutuhkan oleh rakyat biasa yang memahami sebutan "adat" itu dalam atinya sebagai (adat) sopan santun atau dalam arti sebagai hukum. Hazairin menegaskan bahwa adat itu adalah endapan (renapan) kesusilaan dalam masyarakat, yaitu bahwa kaidah-kaidah kesusilaan yang kebenarannya telah mendapat pengakuan umum dalam masyarakat. Menurut Hazirin, hukum adat adalah hukum, baik dalam arti adat sopan santun maupun dalam arti hukum. Dengan demikian Hazairin tidak membedakan antara adat dan hukum adat dan tidak membedakan antara hukum (yang tertulis) dengan kesusilaan (adat, kebiasaan).

\section{D asar Hukum Berlakunya H ukum A dat di Indonesia}

Untuk menjelaskan dasar hukum berlakunya hukum adat di Indonesia, idealnya kita mengetahui dasar-dasar yuridis tentang berlakunya hukum adat, dari jaman kolonial hingga pada masa berikutnya sampai sekarang.

Pada zaman kolonial Belanda sumber hukum yang pertama harus dilihat adalah pasal 75 Regerings Reglement baru (yang disingkat R.R baru), yang berlaku pada tanggal 1 Januari 1920, yang menyatakan bahwa Hukum Eropa akan berlaku bagi golongan Eropa berlaku Hukum Eropa dan bagi orang Indonesia Asli, namun menyatakan dengan sukarela bahwa ia akan menundukkan diri hukum Eropa. Sedangkan dalam lapangan perdata bagi golongan orang Indonesia yang lain, akan berlaku hukum adat dengan syarat tidak bertentangan dengan dasar-dasar keadilan yang diakui umum. Sebaliknya apabila peraturan hukum adat bertentangan dengan

\footnotetext{
16 | bid.

17 Ibid., hlm. 16.
} 
dasar-dasar keadilan atau terdapat suatu masalah yang tidak diatur dalam hukum adat, maka hakim wajib memakai dasar-dasar umum hukum perdata Eropa sebagai pedoman. Pasal 75 RR tersebut dipertegas oleh pasal 130 IS yang menyatakan bahwa daerah-daerah diberi kebebasan untuk menganut hukumnya sendiri.18

Setelah Indonesia merdeka pada tanggal 17 Agustus 1945, sehari berikutnya tanggal 18 Agustus 1945 ditetapkanlah UndangUndang Dasar 1945. Dasar hukum berlakunya hukum adat ketika jaman penjajahan masuk ke wilayah setelah Indonesia merdeka melalui pasal II Aturan Peralihan Undang-Undang Dasar 1945, yang menyatakan bahwa segala badan negara dan peraturan yang ada masih berlaku, selama belum diadakan yang baru menurut undangUndang Dasar.

Pada awal-awal kemerdekaan muncul paham yang hendak memperjuangkan terwujudnya hukum nasional dengan cara mengangkat hukum rakyat, yaitu hukum adat, menjadi hukum nasional.19 Pelopor dari ide tersebut mayoritas adalah golongan tua, suatu ide yang sejak awal dikemukakan oleh nasionalis-nasionalis generasi sebelumnya, yang menyatakan bahwa hukum adat layak diangkat sebagai hukum nasional yang modern. ${ }^{20}$

Dalam Undang-Undang Dasar 1945, secara eksplisit tidak ada satu pasal pun yang menyatakan berlakunya hukum adat di Indonesia. Hal ini berbeda apabila dibandingkan dengan Konstitusi RIS, yang secara konstitusional dapat diketemukan pasal-pasal yang merupakan Iandasan hukum berlakunya hukum adat, sebagaimana dinyatakan dalam pasal 146 ayat (1) yang menyatakan bahwa keputusan kehakiman harus berisi alasan-alasan dan dalam perkara hukuman harus menyebut aturan-aturan undang-undang dan aturan hukum adat yang dijadikan dasar hukuman itu. Pasal 146 ayat (1) Konsitusi RIS tersebut ditegaskan kembali dalam pasal 104 (1) Undang-Undang Dasar Sementara 1950.

\footnotetext{
$18 \mathrm{Ibid}$., hlm.55.

19 Soetandyo Wignjosoebroto, D ari H ukum Kolonial KeH ukum Nasional (Jakarta: RajaGrafindo Persada, 1995), hlm. 240.

20 R. Soepomo, Bab-Bab Tentang H ukum A dat (Jakarta: Pradya Paramita, 2000), hlm. 3.
} 
Pada masa sekarang konfigurasi hukum telah berubah dan hukum adat adalah bagian organik dari hukum negara.21 Realisasi tersebut tertuang dalam Undang-Undang Nomor 4 Tahun 2004 tentang Kekuasaan Kehakiman, yang diatur di dalam pasal 25 ayat (1) yang menyatakan bahwa segala putusan pengadilan selain harus memuat alasan dan dasar putusan tersebut, memuat pula pasal tertentu dari peraturan perundang-undangan yang bersangkutan atau sumber hukum tak tertulis yang dijadikan dasar untuk mengadili. Pasal tersebut diperkuat oleh pasal 28 yang menyatakan bahwa hakim wajib menggali, mengikuti dan memahami nilai-nilai hukum dan rasa keadilan yang hidup dalam masyarakat.

Dari 2 (dua) pasal tersebut di atas dapatlah ditarik kesimpulan bahwa secara implisit hukum adat dapat dijadikan dasar oleh hakim dalam mengadili dan memutus perkara di pengadilan, karena yang dimaksud sumber hukum tidak tertulis dalam pasal 25 ayat (1) adalah hukum adat. Dan yang dimaksud dengan nilai-nilai hukum dan rasa keadilan dalam masyarakat, salah satunya adalah hukum adat, dengan asumsi bahwa hukum adat adalah hukum yang tumbuh dan berkembang di masyarakat. Kedua pasal tersebut memberikan kewenangan kepada hakim dalam memutus perkara dengan mendasarkan pada hukum adat.

\section{Hukum A dat dan Hukum Agraria}

Salah satu realisasi pemikiran penggunaan hukum adat sebagai landasan Hukum Nasional tercermin dalam Undang-Undang Nomor 5 Tahun 1960 tentang Undang-Undang Pokok Agraria, atau yang lazim disebut sebagai UUPA. Di dalam pasal 5 Undang-Undang tersebut dinyatakan bahwa hukum agraria yang berlaku atas bumi, air dan ruang angkasa, berlaku hukum adat sepanjang tidak bertentangan dengan kepentingan nasional dan negara, yang berdasarkan atas persatuan bangsa, dengan sosialisme Indonesia serta dengan peraturan-peraturan yang tercantum dalam Undang-Undang ini dan dengan peraturan perundangan lainnya, segala sesuatu dengan mengindahkan unsur-unsur yang bersandar pada hukum agama.

\footnotetext{
21 Satjipto Raharjo, Hukum A dat dalam Negara Kesatuan Republik Indonesia, dalam Inventarisasi dan Perlindungan $\mathrm{H}$ ak M asyarakat Hukum A dat (Jakarta:Komisi Nasional Hak A sasi Manusia, 2005), hlm. 47.
} 
Di dalam hubungannya dengan konsep atau pengertian hukum adat, perumus UUPA mengartikan hukum adat sebagai "hukum yang asli" yang sesuai dengan kesadaran hukum rakyat banyak. Hanya saja UUPA tidak menjelaskan hukum adat yang akan dijadikan dasar, mengingat di Indonesia tiap daerah memiliki adatnya masing-masing.

Jadi berdasarkan ketentuan pasal 5 UUPA, untuk hukum agraria berlaku hukum adat mengenai tanah. Artinya bahwa segala masalah hukum mengenai tanah harus diselesaikan menurut ketentuan-ketentuan hukum adat. Namun walaupun menjadi dasar dari hukum agraria nasional, tidak semua hukum tanah adat yang asli secara langsung dijadikan dasar melainkan hukum adat yang tidak bertentangan dengan kepentingan nasional dan negara. Dan sebelum dijadikan dasar UUPA, Hukum adat tanah terlebih dahulu harus disesuaikan dan disempurnakan dalam hubungannya dengan negara modern dan dalam hubungannya dengan dunia internasional. Oleh karena itu hukum adat yang dijadikan dasar hukum agraria nasional adalah hukum adat yang telah di-saneer, yang berarti telah dibersihkan cela-celanya serta ditambah kekurangan-kekurangannya supaya dapat berlaku di seluruh wilayah Indonesia.22

Hukum adat sebagai dasar pembentukan hukum agraria nasional menghadapi kendala-kendala tertentu, yang berkait dengan sifat pluralisme hukum adat, dimana masing-masing masyarakat adat mempunyai hukum adatnya sendiri-sendiri, yang tentu saja di dalamnya terdapat perbedaan. Untuk itu dicari persamaanpersamaannya yaitu dengan merumuskan azas-azas/ konsepsi lembaga hukum atau sistem hukumnya. ${ }^{23} \mathrm{Hal}$-hal inilah yang diambil dalam hukum adat untuk dijadikan dasar utama dalam penbentukan hukum agraria nasional, sehingga hukum agraria nasional dapat bercorak sederhana dan dapat menjamin kepastian hukum.

\section{H ukum A dat dan Hukum Harta Perkawinan}

Dalam pasal 1 Undang-Undang Nomor 1 Tahun 1974 tentang Perkawinan dinyatakan bahwa perkawinan adalah ikatan lahir batin

\footnotetext{
22 Urip Santoso, Hukum Agraria dan hak-Hak A tas Tanah (Jakarta: Prenada Media, 2006), hlm. 69

$23 \mathrm{Ibid}$., hl m. 65
} 
antara seorang pria dan seorang wanita sebagai suami isteri dengan tujuan membentuk keluarga (rumah tangga) yang bahagia dan kekal berdasarkan Ketuhanan Yang Maha Esa. Untuk mencapai kebahagiaan tersebut salah satu faktor yang menentukan adalah dibutuhkan suatu kekayaan duniawi guna mencukupi keperluan hidup bersama-sama, yang nantinya akan dipergunakan oleh suami isteri untuk membiayai ongkos kehidupan mereka beserta anakanaknya. Kekayaan duniawi tersebut populer dengan istilah "harta perkawinan".

Salah satu materi hukum adat asli yang dimasukkan dalam Undang-Undang perkawinan adalah pengaturan hukum harta perkawinan. Secara garis besar dalam hukum adat parental, harta perkawinan dibagi menjadi 2 (dua) yaitu harta asal dan harta bersama.24 Pengaturan harta perkawinan menurut hukum adat tersebut kemudian dituangkan dalam pasal 35 Undang-Undang Perkawinan yang menyatakan bahwa harta benda yang diperoleh selama perkawinan menjadi harta bersama. Pasal tersebut dipertegas lagi oleh pasal 37 yang menyatakan bahwa bila perkawinan putus karena perceraian, harta bersama diatur menurut hukumnya masingmasing. Karenanya, di dalam praktik di masyarakat, yang dimaksud dengan hukumnya masing-masing dalam membagi harta, salah satunya adalah hukum adat tentang harta perkawinan.

Menurut hukum adat di Indonesia, apabila terjadi perceraian maka harta bersama pada umumnya dibagi antara suami isteri, yang pada umumnya masing-masing menerima setengah bagian. Namun di beberapa daerah mempunyai kebiasaan yang berbeda, misalnya di daerah Jawa Tengah dikenal asas sagendong sapikul, yang artinya suami memperoleh dua pertiga dan isteri memperoleh sepertiga. Di pulau Bali dikenal asas sasuhun sarembat, yang membagi harta bersama seperti yang berlaku di daerah Jawa Tengah tersebut.25 Sesudah perang dunia kedua, perkembangan menunjukan bahwa kebiasaan sagendong sapikul dan sasuhun sarembat di atas lambat laun

\footnotetext{
${ }^{24} \mathrm{H}$ arta bersama adalah harta yang diperoleh selama perkawinan, tanpa melihat siapa yang memperoleh harta tersebut, sedangkan yang disebut sebagai harta asal/ bawaan adalah harta yang diperoleh sebelum perkawinan, yang nantinya baik suami atau isteri dapat bertindak sepenuhnya untuk melakukan perbuatan hukum mengenai harta bendanya.

25 Wignjodipuro, Pengantar, hlm.158.
} 
tidak berlaku, dengan semakin tumbuhnya keinsyafan atas persamaan hak antara wanita dan pria, sebagaimana keputusan Mahkamah Agung No. 387 K/ Sip./ 1958, tanggal 25 Pebruari 1959, yang menyatakan bahwa di Jawa Tengah, seorang janda mendapat separuh dari harta gono-gini.26 Perubahan ini merupakan bukti bahwa hukum adat bersifat dinamis, sehingga ketika keadaan suatu masyarakat berubah, maka akan terjadi perubahan juga terhadap hukum adatnya.

\section{Konsep H ukum A dat menuju Pembinaan Hukum Nasional}

Hukum adat sebagai hukum asli Indonesia merupakan hukum yang senantiasa mengikuti jiwa dari bangsa masyarakat Indonesia, karena senantiasa tumbuh dan hidup dari kebudayaan masyarakat tempat hukum adat itu berlaku. Dan hukum adat merupakan salah satu penjelmaan dari kepribadian, jiwa dan struktur masyarakat/ bangsa. Hal ini sejalan dengan pendapat Von Savigny, yang menyatakan bahwa isi hukum ditentukan oleh perkembangan adat istiadat dan isi hukum ditentukan oleh sejarah masyarakat dimana hukum itu berlaku. 27

Sejak Indonesia merdeka pada tanggal 17 Agustus 1945, bangsa Indonesia merupakan bangsa yang bebas dan mandiri baik dalam bidang politik, ekonomi, sosial dan budaya. Dan dengan disahkannya Undang-Undang Dasar 1945, negara Indonesia mempunyai dasar-dasar tertib hukum baru, yang mencerminkan kepribadian bangsa Indonesia. Hal ini nampak dari Ketetapan MPRS No. II/ MPRS/ 1960, yang menyatakan secara tegas bahwa pembinaan hukum Nasional haruslah memperhatikan homogenitas hukum dengan memperhatikan kenyataan-kenyataan yang hidup di masyarakat dan harus sesuai dengan haluan negara serta

\footnotetext{
26 Ibid.

27 Von Savigny mengajarkan bahwa hukum mengikuti volksgeist (jiwa/ semangat rakyat) dari masyarakat tempat hukum itu berlaku. Karena volksgeist masing-masing masyarakat berbeda, maka hukum masyarakat juga berbeda. Ajaran hukum ini lebih mengakui eksistensi dari hukum yang timbul dari masyarakat, jika dibandingkan dengan hukum tertulis. Alasan utama yang mendasarinya hal tersebut, karena hukum tertulis tidak selalu mencerminkan hukum yang hidup di masyarakat. Ajaran Von Savigny ini merupakan pencerminan berlakunya hukum adat di Indonesia.
} 
berlandaskan kepada hukum adat yang tidak menghambat perkembangan masyarakat.

Dalam seminar Hukum Adat Nasional pada tanggal $15-17$ Januari 1975 yang diselenggarakan oleh Universitas Gadjah Mada dan Badan Pembina Hukum Nasional, hukum adat diartikan sebagai "hukum Indonesia asli yang tidak tertulis dalam bentuk perundangundangan Republik Indonesia,yang di sana sini mengandung unsurunsur agama". Di dalam seminar tersebut dirumuskan tentang konsep hukum adat dalam rangka pembangunan hukum di Indonesia, antara lain: Pertama, bahwa pengambilan bahan-bahan dari hukum adat pada dasarnya menggunakan konsepsi-konsepsi dan asas-asas hukum dari hukum adat untuk dirumuskan dalam normanorma hukum yang memenuhi kebutuhan masyarakat; kedua, penggunaan lembaga-lembaga hukum adat dimodernisir dan disesuaikan dengan kebutuhan zaman; ketiga, memasukan konsepkonsep dan asas-asas hukum adat ke dalam lembaga-lembaga hukum baru. ${ }^{28}$ Dengan demikian hukum adat masih relevan hingga saat ini karena keadilan dan kebenaran yang merupakan tujuan hukum, wajib merupakan kebenaran dan keadilan yang mencerminkan kebenaran dan keadilan yang hidup di dalam hati nurani rakyat.

A pabila di masyarakat ada sebagian yang berpendapat bahwa hukum adat sudah mengalami perlunakan berlakunya pada era modern seperti ini, memang pendapat tersebut ada benarnya. Fakta ini didukung oleh kenyataan bahwa sistem hukum yang dipakai di negara kita adalah sistem Eropa Kontinental. Pada sistem Eropa Kontinental, hukum tertulis (peraturan perundang-undangan) lebih mempunyai fungsi yang lebih besar di dalam penyelenggaraan negara maupun pengaturan masyarakat, jika dibandingkan dengan hukum yang tidak tertulis. Dengan sistem Eropa Kontinental tersebut, hukum yang lebih dominan adalah yang tertulis, dan hukum yang tidak tertulis (termasuk di dalamnya hukum adat) disebut sebagai pelengkap saja. Akibatnya selama suatu masalah telah diatur di dalam perundang-undangan dan ternyata isinya bertentangan/ berbeda dengan hukum adat, maka secara yuridis formal, yang berlaku adalah hukum tertulis.

28Hilman Hadikusuma, Pengantar IImu H ukum A dat, hlm. 32. 
Namun yang perlu diingat bahwa dalam praktik di masyarakat terkadang hukum tertulis tidak selamanya sejalan dengan perkembangan di masyarakat, sehingga aturan yang tertulis tidak dapat menyelesaikan masalah-masalah yang ada dan terkadang tidak mencerminkan rasa keadilan di dalam masyarakat. Jika hal ini terjadi, maka berarti terjadi kesenjangan antara hukum tertulis dengan hukum yang hidup di masyarakat. Pada kasus demikian, maka hukum tidak tertulislah (hukum adat) nantinya yang akan menyelesaikan masalah tersebut. Hal ini nampak dari amanat Undang-Undang Nomor 4 Tahun 2004 di atas, yang memberikan keleluasaan kepada hakim untuk memahami, menggali dan mengikuti nilai-nilai hukum yang ada di masyarakat.

Dengan demikian eksistensi hukum adat hingga saat ini tetap mempunyai peranan yang penting, terutama dalam pembentukan hukum nasional yang akan datang, terutama dalam lapangan hukum kekeluargaaan. Hukum adat akan menjadi salah satu sumber utama dalam pembentukan hukum tertulis, sehingga aturan tertulis tersebut otomatis merupakan pencerminan dari hukum masyarakat. Dan tentu saja dengan harapan ketika hukum tertulis tersebut sudah diberlakukan, dalam praktik di masyarakat tidak terjadi lagi kesenjangan dengan law in action-nya.

\section{Penutup}

Hukum adat sebagai hukum non statutoir, sesuai dengan sifatnya akan secara terus menerus tumbuh dan berkembang di masyarakat. Sebagai hukum tradisional dan asli hukum Indonesia, hukum adat digolongkan sebagai hukum yang primitif, sehingga tidak jarang banyak pihak yang meragukan eksistensi dan pendayagunaannya pada era modern seperti saat ini. Pihak yang meragukan tersebut menyatakan bahwa hukum adat adalah hukum yang tidak tertulis, sehingga jika dibandingkan dengan hukum yang tertulis, hukum adat dinilai tidak dapat memberikan jaminan kepastian hukum. Alasan lainnya adalah karena pada era unifikasi hukum, sangatlah sulit memadukan atau memilih hukum adat yang akan dijadikan patokan. Hal ini berdasarkan fakta bahwa hukum adat di tiap daerah di Indonesia memiliki perbedaan. 
Sedangkan pihak yang lain, masih mengakui eksistensi pentingnya peran hukum adat pada era modern ini, mengingat bahwa tidak selamanya hukum tertulis yang berupa perundangundangan, dapat selalu mengikuti perkembangan masyarakat. Ketika terjadi kesenjangan seperti itu, maka peran hukum adat akan sangat penting, dengan mengacu pada sifat hukum adat yang bersifat dinamis. Peran penting lainnya, hukum adat sebagai hukum yang lahir, tumbuh dan berkembang di masyarakat, adalah sebagai sumber utama dari penyusunan dan perumusan aturan perundangundangan.

\section{D aftar Pustaka:}

Hadikusuma, Hilman. Pengantar IImu Hukum A dat. Bandung: Mandar Maju, 1992.

Koesnoe, M. Catatan-Catatan terhadap Hukum Adat Dewasa Ini. Surabaya: Airlangga University Press, 1979.

Muhammad, Bushar. A zas-A zas H ukum A dat: Suatu Pengantar. Jakarta: Pradya Paramita, 1994.

Raharjo, Satjipto. "Hukum Adat Dalam Negara Kesatuan Republik Indonesia", dalam Inventarisasi dan Perlindungan $\mathrm{H}$ ak M asyarakat H ukum A dat. Jakarta: Komisi Nasional Hak A sasi Manusia, 2005.

Santoso, Urip. Hukum Agraria dan hak-Hak A tas Tanah. Jakarta: Prenada Media, 2006.

Soekanto, Soerjono. Pokok-Pokok Sosiologi Hukum. Jakarta: RajaGrafindo Persada, 1999.

Soepomo, R. Bab-Bab Tentang H ukum A dat. Jakarta: Pradya Paramita, 2000.

Sumarman, Anto. Hukum Adat Perspektif Sekarang dan M endatang Yogyakarta: Adi Cita Karya N usa, 2003.

Wignjodipuro, Surojo. Pengantar dan Azas-A zas H ukum A dat. Jakarta: Gunung Agung, 1982.

Wignjosoebroto, Soetandyo. Dari Hukum Kolonial ke Hukum N asional. Jakarta: RajaGrafindo Persada, 1995. 